\title{
Podolian cattle: reproductive activity, milk and future prospects
}

\author{
Carlo Cosentino, ${ }^{1}$ Carmine D’Adamo, ${ }^{1}$ Salvatore Naturali, ${ }^{2}$ Giovanni Pecora, ${ }^{1}$ \\ Rosanna Paolino, ${ }^{1}$ Mauro Musto, ${ }^{1}$ Francesco Adduci, ${ }^{1}$ Pierangelo Freschi ${ }^{1}$ \\ ${ }^{1}$ School of Agricultural, Forest, Food, and Environmental Sciences SAFE, University of Basilicata, \\ Potenza; ${ }^{2}$ Veterinary surgeon, San Martino d'Agri (PZ), Italy
}

\begin{abstract}
In the present study, an original article about Podolian cattle and its milk was performed. In detail, the following factors on reproductive career of Podolian cattle in semi-extensive and extensive rearing were analysed: age of calving, gestation lenght, calving interval length, abortions percentage, conception and calving period. Chemical and phisycal parameters (protein, fat and lactose), somatic cell count, lisozyme content and antiradical activity, with ABTS and DPPH assays, of Podolian milk in semiextensive and extensive rearing were evaluated. Finally, suggestions on future prospects of Podolian milk use were proposed: the preparation of hand soap with 5 percentage of podolian milk and the potential role of this breed for prevention and propagation of fire. The data concerning the reproductive career, milk and envinromental role of 677 cows registered in the Herdbook were analysed. The results showed that the $58.56 \%$ of the cows manifested a calving interval of 11-14 months. The reproductive activity occurred in spring; over $70 \%$ of the cows calved in the period February-April. The chemical-physical aspects of milk are in agreement with literature. It presents an high antioxidant activity values for each group $(97.03 \%$ and $97.50 \%$ for ABTS and $52.09 \%$ and $52.60 \%$ for $\mathrm{DPPH}$, semiextensive and extensive system
\end{abstract}

Correspondence: Carlo Cosentino, School of Agricultural, Forest, Food and Environmental Sciences, University of Basilicata, via dell'Ateneo Lucano 10, 85100 Potenza, Italy.

Tel.: +39.0971.205044 - Fax: +39.0971.205604.

E-mail: carlo.cosentino@unibas.it

Key words: Biodiversity; calving interval; cosmetics; milk; Podolian cattle.

Acknowledgements: the research was conducted within the project $L a$ Zoocosmesi per le imprese e l'innovazione di prodotto financed by the Programma Operativo FSE Basilicata 2007-2013, Asse IV Capitale Umano.

Received for publication: 4 April 2017.

Revision received: 11 July 2017.

Accepted for publication: 15 July 2017.

(C) Copyright C. Cosentino et al., 2018

Licensee PAGEPress, Italy

Italian Journal of Agronomy 2018; 13:982

doi:10.4081/ija.2018.982

This article is distributed under the terms of the Creative Commons Attribution Noncommercial License (by-nc 4.0) which permits any noncommercial use, distribution, and reproduction in any medium, provided the original author(s) and source are credited. respectively). The consumer test shows that the subjects appreciated the soap containing 5\% of Podolian milk for different aspect. The data about environmental role were obtained from Podolian cows reared in fifteen grazing areas were monitored for five years during the summer pasture, when the Podolian cattle graze on green grazing areas located in Basilicata region (South of Italy). Therefore, an efficient management of grazing by Podolian cattle could be an important tool to prevent the fire propagation.

\section{Introduction}

The Podolian cattle (Bos taurus podolicus) arrived in Italy from the East Asia across the Danube Hungarian plain is well adapted to the harsh environmental conditions of the inland areas of southern Italy (Abruzzo, Basilicata, Calabria, Campania, Molise and Apulia) thanks to its extraordinary ability to survive and reproduce (Felius et al., 2014). This breed presents a lightweight skeletal structure with strong feet and it is very robust and frugal, currently, about 23,000 head are registered in the Herd Book and the animals are reared on more than 600 farms (Maretto et al., 2012; ANABIC, 2014). In past years, this breed was appreciated for its triple attitude (work, meat, milk). Currently, it is instead selected, monitored and evaluated mainly for the production of meat. The Podolian milk is used exclusively for the production of the typical stretched curd cheeses with good quality. This milk is rich in protein $(4.06 \%)$ and fat $(4.87 \%)$, contains different bioactive components such as peptides, vitamins (C and E), carotenoids and flavonoids with antioxidant properties (Simos et al., 2011). It is also rich in unsaturated fatty acids $(30 \%)$, in particular Omega 3 and Omega 6, important in moisturizing functions for the skin (Marsico et al., 1993). The lactation persists about 68 months with a total daily production between 5 and 10 liters (Parisi, 1950). The Podolian cows do not fit the mechanical milking, they must be milked by hand simultaneously with the calf feeding, it involves the higher costs and comprehensible difficulties (Procopio et al., 2005). The calving interval is one of the most important parameters to evaluate the productive and reproductive efficiency in a livestock and/or population, but the pedoclimatic conditions, and a high coefficient of inbreeding in populations of poor consistency as Podolian breed, make the analysis of these reproductive characters particularly complex. Studies conducted in farms with extensive system (Giourga et al., 1998) have shown that certain factors, such as diet and photoperiod, can influence the length gestation of certain Spanish genetic types. Several studies (Zicarelli et al., 1989) also showed that the most innovative reproductive technologies (synchronization and embryo transfer) had poor results, and only the best weather conditions and increased food availability may influence, in part, the reproductive activity. The long duration of calving interval and of seasonal reproductive 
activity, limit the desired development and success of Podolian cattle. The enhancement of this model (Musto, 2003), in fact, cannot be tied exclusively to the sale of products that this livestock allows to obtain, but must necessarily be accompanied by the improvement of management. A possible alternative employment and exploitation of the Podolian milk may be to use it as an ingredient for the formulation of natural cosmetic products, being a natural tensor, rich in vitamins, minerals, antioxidants, proteins, enzymes and lipids, the milk well promotes the protection and regeneration of the epidermis (Cosentino et al., 2014). The European market, primarily in Denmark, offers cosmetics based on cow's milk, with emollient and moisturizing characteristics, without paraben, inorganic polymers or other synthetic arising. In particular, milk of animals raised on mountain natural grazing not treated with herbicides and chemical fertilizers, is a good basic constituent for the preparation of natural cosmetics such as milksoap (Gilbert et al., 2012).

Nowadays, the survival of the Podolian cattle and the possibilities for consolidation of their breeding, are closely linked to the protection of marginal lands and to the preservation livestock biodiversity. The Pan-European Strategy on Biological Diversity has encouraged, in Italy, the establishment of new protected areas and parks for the protection of extensive rearing system that is oriented towards the breeding of native species in order to combat the abandonment of internal areas (Cosentino et al., 2010). This type of breeding, if managed with rational criteria, may exercise specific actions in the habitat conservation: with the containment of some invasive species and poor food value, it allows to maintain a high plant diversity, with the appearance of floristic specimens also particularly valuable, such as Anacamptis morio, Orchis italics, etc. (Pihl et al., 2001; Freschi et al., 2015). Moreover, grazing animals remove biomass, one of the most important factors for pasture ecosystem management (Leonard et al., 2010). Podolian cattle is well appreciated also for sustainable and ecological management of the available resources.

This article contains the following studies about Podolian cattle conducted in the areas of Basilicata region: i) the seasonality of reproduction and the indices that define the calving interval, and the possible effects of the farming system; ii) chemical-physical characteristics of milk; iii) future employment of milk-cosmetics; iv) environmental role.

\section{Materials and methods}

\section{Evaluation of reproduction index}

This study was conducted analysing data from 24 farms located in different areas (Val d'Agri, Camastra, Alto and Medio Basento) of Basilicata, South of Italy. The farms were selected for the same number of cows, and were divided for rearing system: extensive and semi-extensive. In the extensive system, the grazing was throughout the year without shelter; in the semiextensive system, the grazing was during the year, with shelter only for the colder season. The data concerning the reproductive career of 677 cows registered in the Herdbook were analysed. For each cow, the dates and the age of the calving have been detected, defining the gestation length, the calving interval and the conception and calving period. In both farming systems, the natural service is with a sex ratio of 1 bull per 30 cows in order to get the calvings in a limited period.

\section{Chemical and physical analysis of Podolian milk}

Bulk cow milk was taken on the same day from 4 farms ( 2 for extensive sistem, 2 for semi-extensive sistem) that used mechanical milking. The farms are situated at about $700 \mathrm{~m}$ above sea level in National Park of Appennino Lucano, Basilicata. After collection, milk aliquots were immediately refrigerated at $4^{\circ} \mathrm{C}$ and transported to the laboratory for analytical determinations. On milk samples we measured pH (HI931410, Hanna Instruments, Padova, Italy), protein, fat, and lactose content according to the International Dairy Federation Standard (ISO, 2013) by Milkoscan FT 6000 FT 6000 (Foss Electric, Hillerod, Denmark). Somatic cells count, expressed as SCS $(\log 10 \mathrm{n} \times 1000 / \mathrm{mL})$ (ISO 13366-2:2006) we determined using a Fossomatic 5000 (Foss Electric A/S). Moreover, we enumerated bacteria total count. All determinations were carried out in triplicate.

Lysozyme quantity of Podolian milk was determined by HPLC fractionation using a reversed-phase column. Sample milk preparation, column equilibration and elution were performed according to Cosentino et al. (2016). The chromatographic separations were run on a Synergi MAX-RP $80 \AA$ column $(150 \times 4.6 \mathrm{~mm}, 4 \mu \mathrm{m}$ particle size) from Phenomenex (Torrance, CA, USA) with a MAX$\mathrm{RP}$ guard column $(4 \times 2 \mathrm{~mm}$ id). Injection volume was $20 \mu \mathrm{L}$ and flow rate was $0.8 \mathrm{~mL} / \mathrm{min}$. The mobile phase consisted of a gradient of water (A) and acetonitrile (B) both containing $0.1 \%$ trifluoroacetic acid (v/v). Eluting conditions are: $0 \mathrm{~min} 80 \% \mathrm{~A}$ and $20 \%$ B; $9 \min 60 \% \mathrm{~A}$ and $40 \% \mathrm{~B} ; 15 \mathrm{~min} .60 \% \mathrm{~A}$ and $40 \% \mathrm{~B} ; 20 \mathrm{~min}$. $80 \% \mathrm{~A}$ and $20 \% \mathrm{~B}$. Detection was carried out by fluorescence detector (Jasco FP-2020 Plus-Intelligent-fluorescence detector) set at $280 \mathrm{~nm}$ excitation and $350 \mathrm{~nm}$ emission. Calibration curves were acquired with known amounts of HEW lysozyme in the concentration range of 5 to $100 \mathrm{mg} / \mathrm{L}$.

Antiradical activity of Podolian milk was evaluated by using both DPPH (2,2-diphenyl-1-picrylhydrazyl) and ABTS (2,2'-azinobis (3-ethylbenzthiazoline-6-acid)) assays (Cosentino et al., 2015). Both tests were carried out in triplicate.

DPPH assay: The stock radical solution of DPPH was prepared by dissolving $20 \mathrm{mg}$ of DPPH in $15 \mathrm{~mL}$ of ethanol. After $1 \mathrm{~min}$ of agitation with Vortex, $1 \mathrm{~mL}$ of stock DPPH solution was diluted in ethanol (1:30). $50 \mu \mathrm{L}$ of milk were added to $950 \mu \mathrm{L}$ of DPPH solution and incubated into the darkness for $30 \mathrm{~min}$ at room temperature. After centrifuging (5 min, $8000 \mathrm{rpm}$ ), absorbance was measured at $515 \mathrm{~nm}$ against the reference solvent (ethanol) by using spectrophotometer UV-Vis (LKB Biochrom 4050 Ultrospec II).

ABTS assay: The stock solution of the ABTS radical was prepared by dissolving $38 \mathrm{mg}$ of (ABTS) in $10 \mathrm{~mL}$ of an aqueous sodium persulphate solution $(2.45 \mathrm{mM})$. The mixture was dark stored for $12-16 \mathrm{~h}$. For the analysis, $1 \mathrm{ml}$ of stock ABTS $\bullet+$ solution was diluted in ethanol (1:30). $20 \mu \mathrm{L}$ of milk sample was added to 980 $\mu \mathrm{L}$ of ABTS $\bullet+$ solution. Milk samples were reacted with ABTS $\bullet+$ working solution for $2 \mathrm{~h}$ in incubation into the darkness at room temperature. After centrifuging ( $5 \mathrm{~min}, 8000 \mathrm{rpm}$ ), absorbance was measured at $734 \mathrm{~nm}$ against the reference solvent (ethanol). The solutions were prepared fresh for the analysis.

Antioxidant activity of cow milk was evaluated through the Radical Scavenging Activity (RSA\%) utilizing the following formula: Radical Scavenging Activity $(\mathrm{RSA} \%)=(1-\mathrm{Ai} / \mathrm{A} 0) \times$ $100 \%$, where $\mathrm{Ai}$ is the absorbance of sample and A0 is the absorbance of colorimetric radical substance.

\section{Preparation and efficacy test of hand soap}

Hand soap supplemented with 5\% percentage of Podolian milk was prepared by specialized and certified laboratory. The surfac- 
tants used are derived from cornstarch and coconut oil. The abrasive action is carried out by plant micro-granules obtained by crushing the shell of hazelnut and almond; the fragrance is given by the essential oils of orange and rosemary, able to eliminate bad odours. The Podolian milk and vegetable Glycerine help to restore the hydro-lipid barrier of the skin. The basic formula of liquid soap is the following according to International Nomenclature of Cosmetic Ingredients (INCI): aqua, sodium lauroyl sarcosinate, cocamidopropyl betaine, acrylates copolymer, lauryl glucoside, lac, citrus autantium dulcis oil, prunus amygdalus dulcis shell and corylus avellana shell, glycerin, benzyl alcohol, rosmarinus officinalis oil, sodium benzoate.

The soap was tested by 8 women and 7 men regular consumers of liquid soap recruited from our University Campus. Their age was in the range 22 to 54 years. For evaluating the effectiveness in removing dirt, in relation to the target professional profiles identified in our previous study for willingness to buy (Cosentino et al., 2014), soiling products were employed, such as engine oil, grease workshop, plaster paste, universal soil, extra virgin olive oil, margarine, dough for bread, charcoal, minced meat. The soiling of the hands, the movements and the operations of washing, including the amount of soap used was standardized. During efficacy test, the individual washes are controlled for the amount of product used, the times and the movements of cleaning.

\section{Environmental role of Podolian cattle}

In fifteen grazing areas located in 14 different municipalities of Basilicata, the occurrences of fire were monitored for 5 years, 2010-2014 (Pecora et al., 2015). In these areas only Podolian cattle grazed (Figure 1). The study areas were drawn by using open source GIS software, the burned areas were recorded by using GPS (Garmin Montana 60T) and classified in two classes: wooded burned area (WBA) and no-wood burned area (NWBA). The grazing and burned areas were analyzed by GIS technique. The extension (ha) of fire damage was measured within and in the surroundings of each grazing areas (no-grazing area) by overlay.

For livestock production system, data of consistency and of live weight on Podolian cattle kept on each grazing area were obtained in personal interviews with 15 farm operators. The number of animals was used to calculate the number of Livestock Unit, which, according to the European official regulation (Commission
Regulation - EC n. 1200/2009), it is defined as follows: 0.0 LU for calves younger than 6 months, $0.6 \mathrm{LU}$ for cattle between 6 months and 2 years, and 1.0 LU for cattle older than 2 years. For each area, the stocking density (SD) was calculate by dividing the number of LU of each area by the extension (ha) of the same area.

For pasture utilization, the potential feed intake of Podolian cattle in each area was estimated according to Grenet et al. (1987): dry matter intake for adult cattle is $14 \mathrm{~g} \mathrm{DM} / \mathrm{kg} \mathrm{LW}$ (DM dry matter, LW live weight). While the live average weight was $605 \mathrm{~kg}$, mean of data reported on farm registers. The removal of potential biomass by Podolian cattle was estimated by multiplying the feed intake calculated in each area for 120 , summer season characterized by highest incidence of fire, as well as the peak of the dry and hot temperatures combined with the lowest rainfall (Pecora et al., 2015).

\section{Results and discussion}

\section{Evaluation of reproduction index}

The results showed that the average gestation length was 281 days. Similar values were reported by Caballero de la Calle (2003) in a study about the breed de Lidia. The neonatal mortality rate was $3.15 \%$, while spontaneous abortions were $1.95 \%$ (Figure 2). There were not marked differences between the two rearing systems, but only slight improvements in reproductive indices in semi-extensive rearing due, probably, to theshelter in cold season and to the dietary supplementation. The cases of neonatal mortality $(2.7 \mathrm{vs}$ $3.6 \%)$ and of spontaneous abortion (1.8 vs 2.1\%) were lower in semi-extensive than extensive rearing. The calving concentration in the period from February to April was higher in semi-extensive than in the extensive rearing (72.51 vs 70.66\%; Figure 2). According to Panella et al. (1995) and Montemurro (1996), the facility in calving performing, even in harsh environmental conditions, is due both to the pelvis anatomy that to the functional gymnastics caused by the intensive grazing intrinsic in both rearing systems. The reproductive activity was higher in the late spring and early summer, with the highest concentration of conceptions in May for both considered systems. The calving interval was between 11 and 14 months in $58.56 \%$ of the cows, it increases up

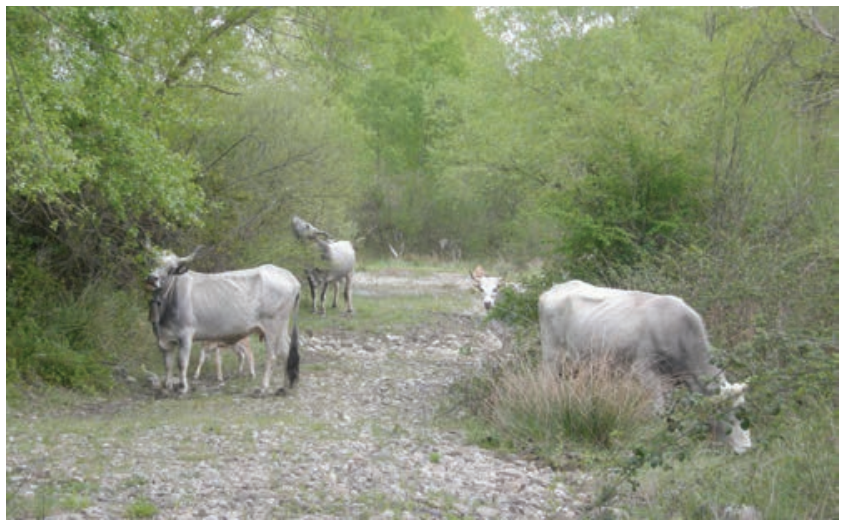

Figure 1. Podolian cows on grazing in the national park of Appenino Lucano.

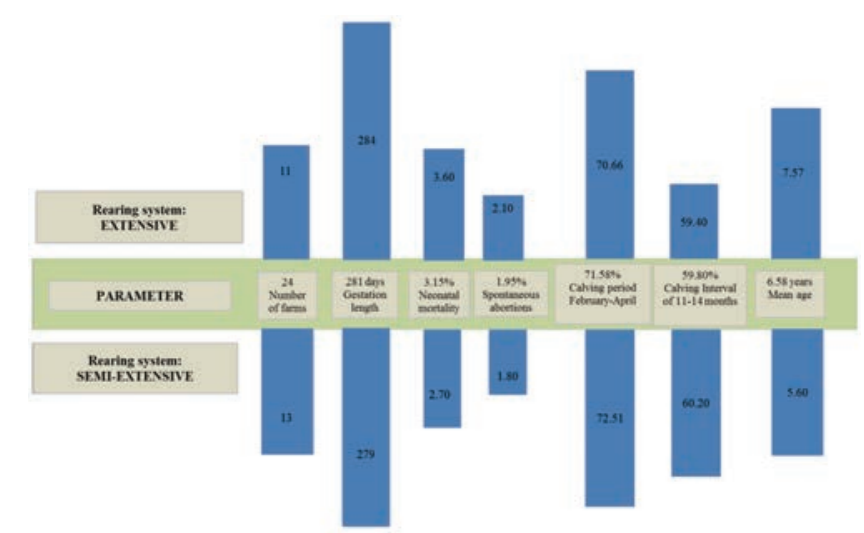

Figure 2. Comparison among the parameters studied in the two rearing systems. 
to 24 months or more in the $38.24 \%$ and is less than 11 months in $3.2 \%$ (Figure 3 ). In our study the percentage of cows with a calving interval within 14 months was lower than that one (70-80\%) reported by Montemurro (1996) in a similar production area. In the semi-extensive rearing system, a greater percentage of cows was observed with a calving interval between 11 and 14 months than the extensive rearing $(60.20 \%$ vs $59.40 \%)$. The improvement could be due to the reduction of the inbreeding coefficient, as the significant increase in animals registered in the Herdbook $(+26.51 \%)$ (ANABIC, 2014) during the last decade and the subsequent reduction of mating among relatives. In the semi-extensive rearing system, in addition, the improvement of reproductive parameters may also be due to a greater quality and availability of forage that, by reducing the energy deficit, reduces the marked seasonality of reproductive characters typical of the Italian beef cattle (Panella et al., 1995). The data show also a cyclical average duration in calving interval of total observed cattle (Figure 3), with two peaks: the one at $12^{\text {th }}$ month $(20.43 \%)$ and a second one at $24^{\text {th }}$ month $(6.00 \%)$. The calving period is concentrated from January to June for $80 \%$ of total observed cattle, February March and April are the months with the highest concentration of calving (71.05\%), only $25.2 \%$ of the calves occurs in mid-summer (July-August) (Figure 4). The data reported are difficult to compare with other studies and other Italian rustic breeds (Maremmana, Romagnola, Marchigiana, Chianina), because the analized parameters depend on environmental factors and on observed areas (Sargentini et al., 2009).

The average age of the observed cows in the two rearing systems is of 6.58 years, with a minimum of 4 and maximum of 13 years. The longevity is a distinctive feature of farming systems, especially in farms with extensive system, results in a low culling index.

\section{Chemical and physical analysis of Podolian milk}

Several experimental studies have shown that milk from cows fed on pasture has particular characteristics compared to the milk of cows fed indoors. The grazing influences the most important chemical and biological parameters defining the quality of milk (fat, protein, urea, somatic cells).

In Table 1 were reported the chemical composition of Podolian

Table 1. Chemical-physical aspects of Podolian milk for each rearing system.

\begin{tabular}{lcccc} 
Parameters & \multicolumn{2}{c}{ Semiextensive } & \multicolumn{2}{c}{ Extensive } \\
& Mean & \pm S.D. & Mean & \pm S.D. \\
pH & 6.65 & \pm 0.05 & 6.68 & \pm 0.06 \\
Protein, g/100 g & 3.60 & \pm 0.06 & 3.65 & \pm 0.05 \\
\hline Fat, g/100 g & 3.96 & \pm 0.05 & 4.00 & \pm 0.05 \\
Lactose, g/100 g & 5.11 & \pm 0.04 & 5.20 & \pm 0.06 \\
\hline Lysozyme, mg/L & 0.25 & \pm 0.04 & 0.26 & \pm 0.05 \\
RSA\%, DPPH & 52.09 & \pm 3.40 & 52.60 & \pm 3.85 \\
\hline RSA\%, ABTS & 97.03 & \pm 1.06 & 97.50 & \pm 1.20 \\
SCC, cell/mL & 76,600 & \pm 500 & 78,900 & \pm 700 \\
\hline Bacterial count, CFU/mL & 340,000 & \pm 1300 & $365,000 \pm$ & 1200 \\
\hline S.D,
\end{tabular}

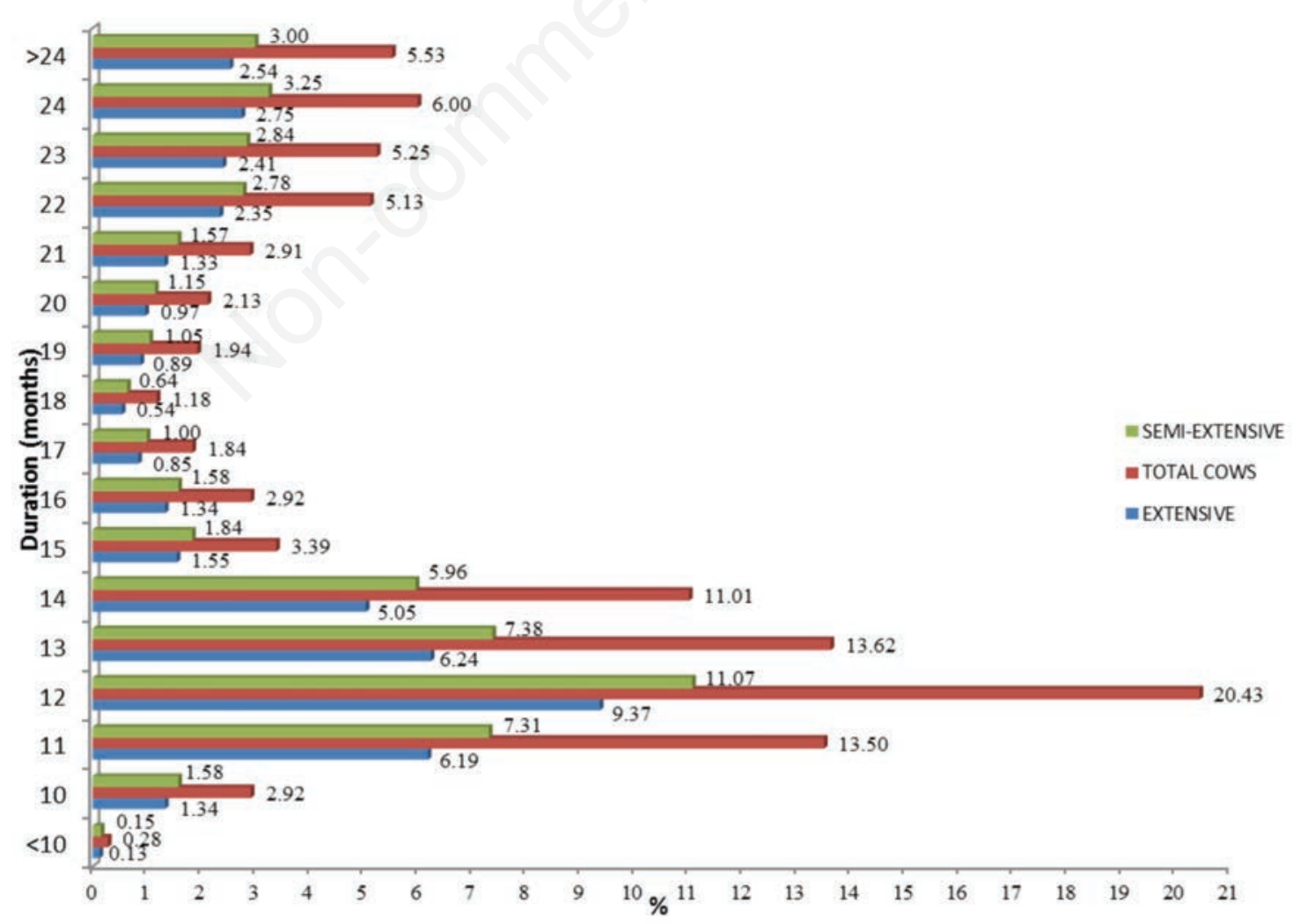

Figure 3. Calving interval in each rearing system and in total observed Podolian cows. 
milk rearing in semiextensive and extensive system. There were not marked differences between the two rearing systems. The antioxidant activity of Podolan milk is very high for both assay (97.03\% and $97.50 \%$ for ABTS and $52.09 \%$ and $52.60 \%$ for DPPH, semiextensive and extensive system respectively). Podolian milk shows a content of lysozyme in trace in agreement of literature. In cow milk lysozyme content was generally $<0.6$ ppm, according to Claeys et al. (2014) and varies depending on the lactation period, at the beginning it is higher (Dimitrov et al., 2009).

\section{Efficacy test of hand soap}

The aim of this preliminary study was to evaluate the effect of an alternative ingredient on some sensory aspects of skin in fifteen volunteers. The results of our study show that the subjects appreciated the soap containing 5\% of Podolian milk for different aspect. Results showed maximum preference for following parameters: the exfolianting power, the cleaning power, the skin hydration and the perfume that the soap leaves on the hands. Cow milk preparations (face and body creams, cleansing milk, and tonic) are the most known by consumers. Dairy products are good remedies for imperfect skin, Vitamins B, A and E contained in the milk have a regulating and regenerative effect. Proteins and other components have a strong absorption capacity and water retention, encouraging a high degree of hydration of the skin, and preventing the degradation of the epidermal cells (Temmuujin et al., 2006). Cotte (1991) put in evidence an increased elasticity and a calming effect of the skin of a cream containing cow milk. These results confirm that podolian milk could be a cosmetic component suitable for all skin types thanks to its balancing skin's moisture.

\section{Environmental role by Podolian cattle}

GIS analysis showed that fire affected only 4 areas of 14 municipalities of Basilicata: 1, 8, 12 and 15 (Figure 5).

Results showed in the Area 1 (Abriola/Pignola municipalities), the burned area had an extension of 120 ha in 2011, and 3.35 ha in 2012. In the grazing area (2011), 25 ha of WBA and 24 ha of NWBA were recorded, with a percentage incidence on the total grazing area of $4.7 \%$ and $4.4 \%$, respectively. In the no-grazing area, there were 35 ha of WBA and 41 ha of NWBA, with a percentage incidence on the total no-grazing area (buffer area) $7.5 \%$ and $8.8 \%$, respectively. In the $2012,3.35$ ha of NWBA were recorded in the grazing area ( $0.6 \%$ of grazing area). In 2012 in the Area 8 (Ferrandina municipality), there were only 5 ha of WBA in the grazing area (1.5\% of total area); in the Area 12 (Pescopagano municipality), the burned area had an extension of 2 ha of NWBA $(0.3 \%$ of total of no-grazing area). During 2011, in the Area 15, there were 1 ha of WBA $(0.1 \%$ of total grazing area $), 7$ ha of WBA and 3.5 of NWBA (1.8 and $0.9 \%$ of total of no-grazing area, respectively). These results show that in the grazing areas, the incidence of fire propagation was very low.

The potential effect of removal biomass by Podolian cattle may be useful as a tool to prevent the fire propagation. In fact, these breed showed, during the time, a number of positive environmental effects, such as increased climate stability, improved soil functionality, water quality and footprint and preservation from

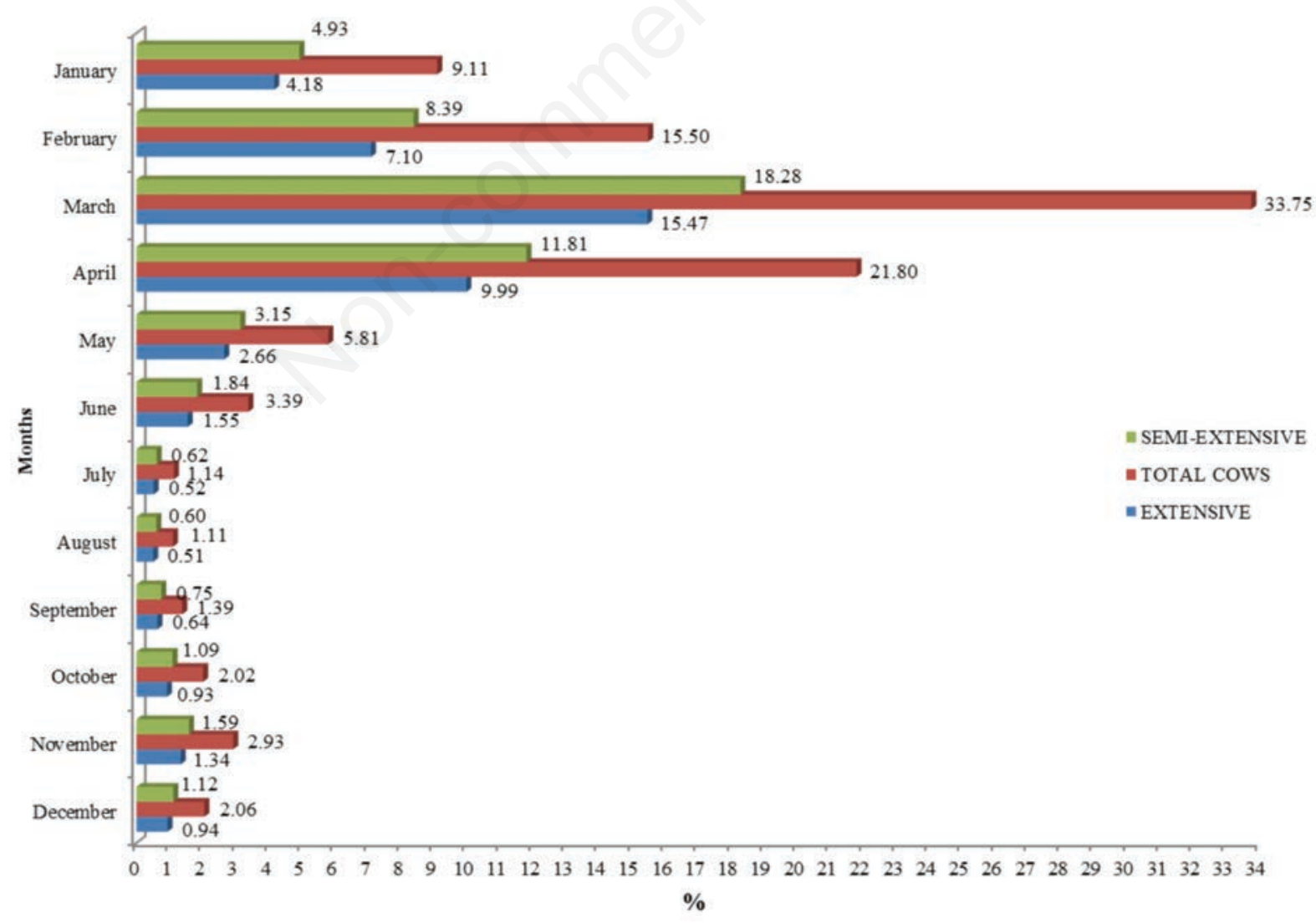

Figure 4. Calving frequency in each rearing system and in total observed Podolian cows. 
fires (Freschi et al., 2015).

In Figure 6 are reported the main characteristics of Podolian cattle reared in the areas. Concerning stocking density (SD), in two grazing areas (Area 6 and 9) the parameter was higher than in the other grazing areas. This was due to both small grazing surface and high consistency of Podolian cattle. SD resulted to be below the threshold values laid down in Nitrates Directive (91/676/CEE). However, it is recommended to keep a low livestock intensity in order to not create overgrazing, which in turn may lead to soil compaction by trampling, reduction of water infiltration, and increased surface run-off and erosion (Strand et al., 2014; Freschi et al.,
2015). Moreover, the value of dry matter intake for grazing time (DM) was the highest in 2013 due to substantial cattle turnover. This estimation allowed understanding how the Podolian cattle browsing may be an important tool to reduce the fuel in order to create a horizontal and/or vertical fuel break. In fact, the Podolian cattle may be an interesting tool for fuel reduction, just like goat (Lovreglio et al., 2014). Obviously, this goal should be achieved through appropriate measures, such as the use of metallic or electrified fence in order to maintain an appropriate stocking density, for browsing both the available foliage and twigs from all woody plants and all herbaceous vegetation.
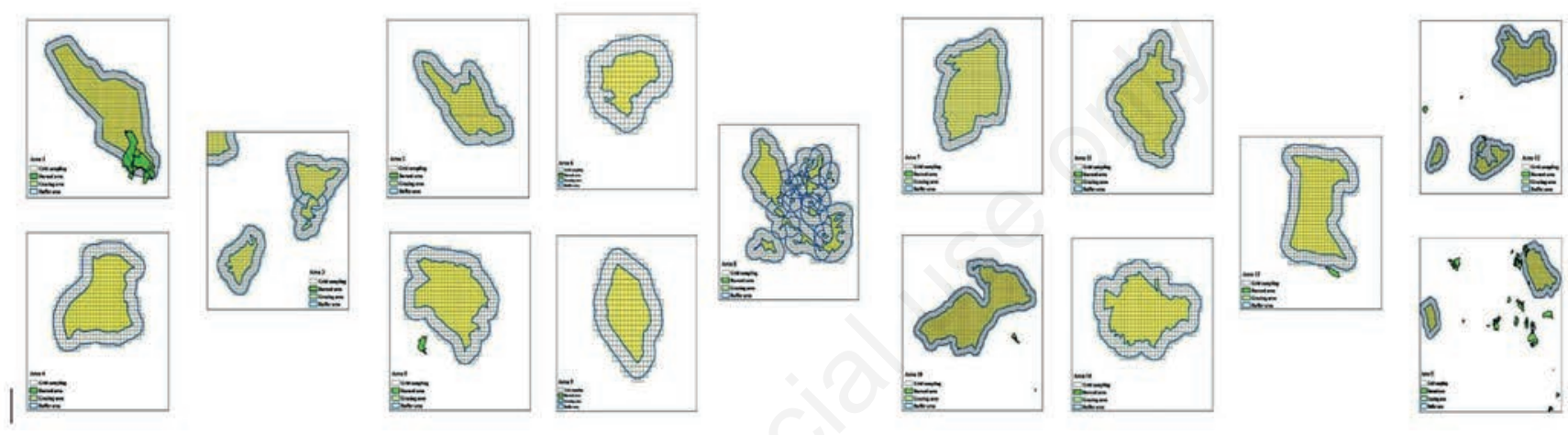

Figura 5. Grid sampling mapping: areas 1 to 15 .

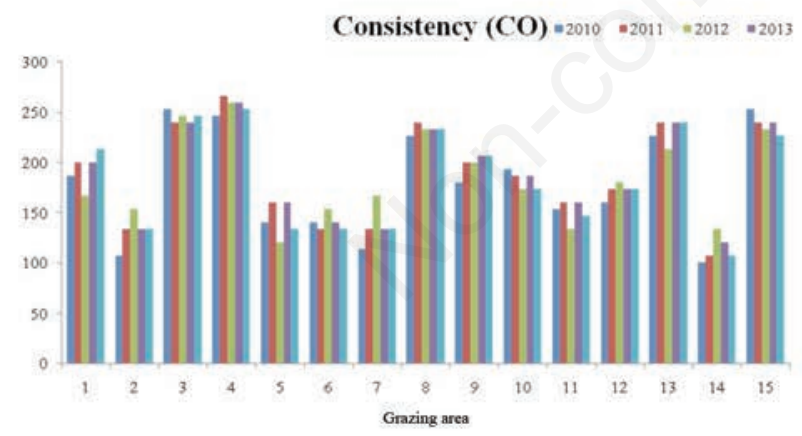

Stocking density per hectare (SD)

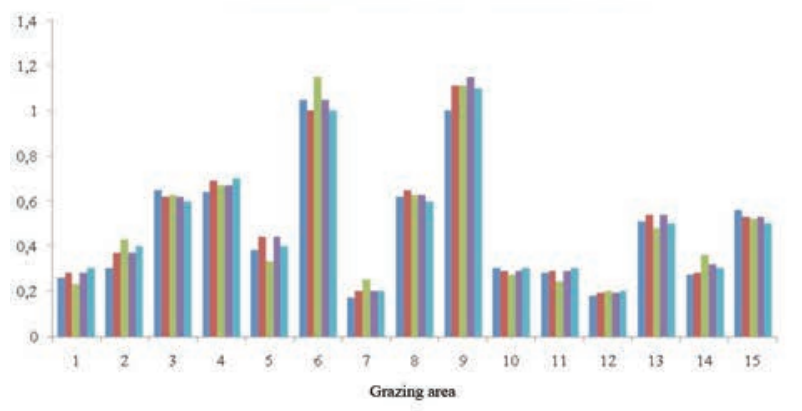

Livestock Unit (LU)

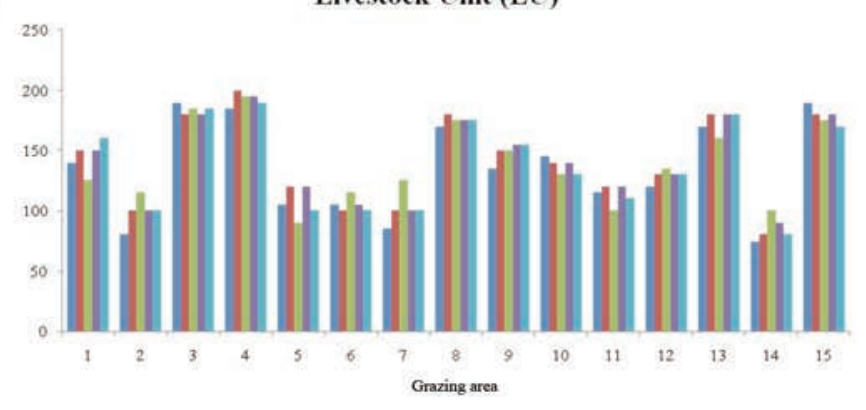

Dry matter intake for grazing time (DM)

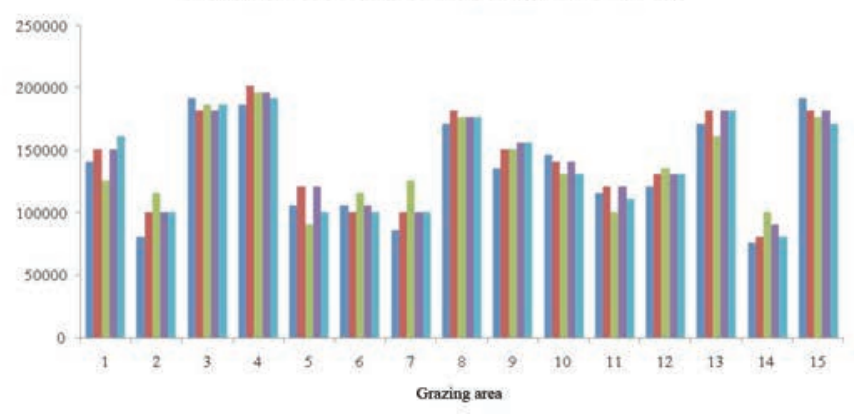

Figure 6. Feed intake estimation of Podolian cattle from 2010 to 2014 - Potential feed intake of Podolian cattle. 


\section{Conclusions}

This study on the Podolian cattle from the southern Apennines confirms that environmental factors affect the reproductive features. The Podolian cattle is, in fact, characterized by a high concentration of births in spring, when the natural pastures and meadows are in maximum productivity, with direct effects on the physiological state of the cows and on the milk production. This feature allows the rational use of spontaneous forage production. Despite the high containment of the rearing costs, the trade in veal calves depends on the age and live weight during the year, with a maximum between August and December (subjects 15-18 months). Moreover, the calving interval is quite high and shows a periodic trend with maximum at $12^{\text {th }}$ and $24^{\text {th }}$ months. Thus, the preservation of this cattle and the biodiversity conservation in situ native, involves improving the performance and control of inbreeding. Furthermore, we reported for the first time in literature, the chemical-physical aspects of podolian milk about fat, lactose, protein (in particular lysozyme) contents and about $\mathrm{pH}$, bacterial count and antioxidant activity values. Due to the high antioxidant activity of this milk, the Podolian milk should be employed in cosmetics. For the revaluation of Podolian milk, we chose to use it as raw material for a skincare product that was positively evaluated by 15 testers. The placing of a new soap hands in the cosmetic industry would allow to small breeders of Podolian cattle to improve their incomes. The use of Podolian milk to realize a hand soap with exfoliating and cleaning power but delicate and emollient, it aims to capture the large target of consumers of effective products but natural and respectful of the skin.

Concerning grazing, the prescribed grazing with Podolian cattle can reduce the fuel load of shrublands, grassland in the short term by partially reducing woody fuels. Moreover, livestock grazing may reduce fire ignition potential and spread by removing live and dead herbaceous vegetation and accelerating litter decay through trampling. However, the stocking density should not excessive in order to manage the pastureland and to reduce the fire propagation. In conclusion, exploiting effectively the local resources, this breed can be regarded as a genetic resource to improve the economy in the marginal areas in a sustainable and environmentally friendly way.

\section{References}

ANABIC, 2014. Associazione Nazionale Allevatori Bovini Italiani da Carne. Consistenze libro genealogico. Available from: http://anabic.it/index1.html

Claeys WL, Verraes C, Cardoen S, De Block J, Huyghebaert A, Raes K, Dewettinck K, Herman L, 2014. Consumption of raw or heated milk from different species: An evaluation of the nutritional and potential health benefits. Food Control. 48:188-201.

Cosentino C, Freschi P, Paolino R, 2010. Biodiversità zootecnica nei territori montani: l'allevamento asinino, una possibile alternativa. Quad. SoZooAlp. 6:231-8.

Cosentino C, Labella C, Elshafie HS, Camele I, Musto M, Paolino R, D'adamo C, Freschi P, 2016. Effects of different heat treatments on lysozyme quantity and antimicrobial activity of jenny milk. J. Dairy Sci. 99:5173-9.

Cosentino C, Labella C, Musto M, Paolino R, Naturali S, Freschi P, 2015. Full Length Research Paper: Effect of different physical treataments on antioxidant activity of jenny milk. Intern. J.
Agricult. Sci. 5:874-7.

Cosentino C, Valentini V, Musto M, Paolino R, Freschi P, Calluso A M, Pecora G, D'Adamo C, 2014. Zoo-cosmetics: new opportunity for podolian cattle husbandry. pp 331-337 in X Convegno Nazionale sulla Biodiversità, Atti X Convegno Nazionale sulla Biodiversità, Copyright CRA-Centro di Ricerca per lo Studio delle Relazioni tra Pianta e Suolo, 3-5 Settembre 2014, Roma, Italy.

Cotte J, 1991. Le lait, una matière d'avenir pour la cosmétique. Lait 71:1213-24.

Dimitrov T, Sotiro VL, Mihaylova G, Tzankova M, Naydenova N, Beev G, 2009. Lysozyme content in buffalo colostrum. Agri. Sci. Technol. 1:1-3.

Felius M, Beerling M, Buchanan DS, Theunissen B, Koolmees PA, Lenstra JA, 2014. On the history of cattle genetic resources. Diversity 6:705-50.

Freschi P, Musto M, Paolino R, Cosentino C, 2015. Grazing and biodiversity conservation: highlights on a Natura 2000 network site. pp 271-288 in The Sustainability of Agro-Food and Natural Resource Systems in the Mediterranean Basin. Editor Antonella Vastola School of Agricultural, Forestry, Food and Environmental Science (SAFE) University of Basilicata Potenza, Italy.

Gilbert L, Picard C, Savary G, Grisel M, 2012. Impact of polymers on texture properties of cosmetic emulsions: a methodological approach. J. Sensory Stud. 27:392-402.

Giourga H, Margaris NS, Vokou D, 1998. Effects of grazing pressure on succession process and productivity of old fields on Mediterranean islands. J. Environ. Manag. 22:589-96.

Grenet N, Mlcol D, Billant J, D'Hour P, Giraud JM, Leconte D, Parrassin PA, Pecatte JR, 1987. Simplification du pâturage pour les troupeaux bovins allaitants et les bovins d'élevage. Fourrages. 111:283-98.

ISO, 2013. Milk and liquid milk products - Guidelines for the application of mid-infrared spectrometry (ISO 9622: 2013/IDF 141:2013). International Organization for Standardization (ISO), Geneva, Switzerland.

Leonard S, Kirkpatrick J, Marsden-Smedley J, 2010. Variation in the effects of vertebrate grazing on fire potential between grassland structural types. J. Applied Ecol. 47:876-83.

Lovreglio R, Meddour-Sahar O, Leone V, 2014. Goat grazing as a wildfire prevention tool: a basic review. iForest Biogeosci. Forestry 7:260-8.

Maretto F, Ramljak J, Sbarra F, Penasa M, Mantovani R, Ivankovic' A, Bittante G, 2012. Genetic relationships among Italian and Croatian Podolian cattle breeds assessed by microsatellite markers. Liv. Sci. 150:256-64.

Marsico G, Di Trana A, La Notte E, Muscio A, 1993. Influenza del sottosistema di allevamento sulla composizione chimica e su quella acidica del grasso di latte di bovine Podoliche. Archiv. Vet. Ital. 44:108-17.

Montemurro N, 1996. Il bovino podolico: attualità e prospettive future. Taurus VIII 87:90-1.

Musto M, 2003. Consumer concern e potenzialità del modello Podolico. Large Anim. Rev. 9:17-20.

Panella F, Filippini F, Sarti FM, 1995. Indagine preliminare su alcuni caratteri riproduttivi delle razze bovine italiane da carne ai fini del miglioramento genentico. Taurus VII 31-3.

Parisi O, 1950. I Bovini. Ed. U.T.E.T., Torino, Italy.

Pecora G, Musto M, D’Adamo C, Adduci F, Freschi P, Cosentino C, 2015. GIS system and livestock field survey as tools to manage the potential reducing of fuel load for fire prevention. J. Agr. Informatics. 6:57-66. 
Pihl S, Ejrnas R, Sogaard B, Aude E, Nielsen KE, Dahl K, Laursen JS, 2001. Habitats and species covered by the EEC Habitats Directive. A preliminary assessment of distribution and conservation status in Denmark. - National Environmental Research Institute, Denmark. NERI Technical Report No 365:121.

Procopio RT, Acciaioli A, Franci O, 2012. La razza bovina Podolica: sistemi di allevamento nell'area di origine. Quad. SoZooAlp. 7:7.

Sargentini C, Giorgetti A, Tocci R, Lorenzini G, Martini A, 2009. Production diversifying in Maremmana breed as remedy for seasonal calving. On the tracks of podolics Proceedings of The Internatinal Congress, Anno XX 3:289.

Simos Y, Metsios A, Verginadis I, D'alessandro AG, Loiudice P, Jirillo E, Charalampidis P, Kouimanis V, Boulaka A,
Martemucci G, Karkabounas S, 2011. Antioxidant and antiplatelet properties of milk from goat, donkey and cow: An in vitro, ex vivo and in vivo study. Inter. Dairy J. 21:901-6.

Strand EK, Karen Launchbaugh L, Ryan Limb F, 2014. Livestock grazing effects on fuel loads for wildland fire in sagebrush dominated ecosystems. J. Rangeland Applic. 35-57.

Temuujin J, Senna M, Jadambaa TS, Burmaa D, Erdenechimeg S, Amarsanaa J, 2006. Characterization of nanoporous materials prepared from montmorillonite clay and its application to the decolorization of mare's milk oil. J. Porous Mat. 13:49-53.

Zicarelli L, Capogreco B, Gualtieri G, Esposito L, 1989. Sincronizzazione dei calori e inseminazione strumentale in bovine podoliche. Taurus I 6:135. 